\title{
PENGGUNAAN BAHASA BAKU DALAM KARYA ILMIAH MAHASISWA
}

Dikirim tanggal 27 September 2017 Diterima 26 Desember 2017 Dipublish 27 Desember 2017

Oleh:

Jamilah

Universitas Terbuka Banjarmasin

Email: saya.jamilah@gmail.com

\begin{abstract}
This paper describes the things that need to be considered how the use of standard language in scientific work of students. The variety of languages used in scientific papers is the variety of raw materials. Standard language is the standard language used in scientific circles. There are rules that need to be fulfilled in the writing, that is in accordance with Ejaan Yang Disempurnakan (EYD). Things to note are the capitalization and oblique letters, the form of foreign word absorption, the use of improper word situations, cutting words, and redundant words.
\end{abstract}

Key word: standart language, scientific paper.

\begin{abstract}
ABSTRAK
Tulisan ini mendeskripsikan tentang hal-hal yang perlu diperhatikan bagaimana penggunaan bahasa baku dalam karya ilmiah mahasiswa. Ragam bahasa yang digunakan pada karya ilmiah adalah ragam baku tulis. Bahasa baku adalah bahasa standar yang digunakan dalam kalangan ilmiah. Ada kaidah-kaidah yang perlu dipenuhi dalam penulisan tersebut, yaitu sesuai dengan Ejaan Bahasa Indonesia Yang Disempurnakan (EYD).Hal-hal yang perlu diperhatikan adalah penulisan huruf kapital dan miring, bentuk penyerapan kata asing, penggunaan kata yang tidak tepat situasinya, pemotongan kata, dan kata-kata mubazir.
\end{abstract}

Kata kunci: bahasa baku, karya ilmiah 


\section{Pendahuluan}

Fungsi bahasa ada beberapa macam, di antaranya adalah sebagai alat komunikasi. Mahasiswa sebagai penulis karya ilmiah berupaya mengomunikasikan hasil pikirannya kepada pembaca. Untuk itu diperlukan sarana dalam melakukannya, yakni bahasa Indonesia ragam tulis, khususnya adalah ragam baku tulis.

Ragam baku adalah ragam yang dilembagakan dan diakui oleh sebagian besar warga masyarakat pemakainya sebagai bahasa resmi dan sebagai kerangka rujukan norma bahasa dalam pengunaannya (Arifin

dan Tasai, 2010). Oleh karena itu, penulisan karya-karya ilmiah, baik berupa buku-buku teks pelajaran, buku-buku ilmiah maupun karya tulis ilmiah lainnya menggunakan ragam baku tulis sebagai standar penulisannya.

Mahasiswa diwajibkan untuk dapat membuat suatu karya ilmiah. Hal ini dikarenakan mahasiswa diharuskan mampu berpikir secara kritis, sistematis dan dapat dipertanggungjawabkan secara ilmiah. Tidak semua mahasiswa mampu menulis karya ilmiah dengan menggunakan bahasa Indonesia yang baik dan benar. Tulisan ini bermaksud untuk membahas mengenai bagaimana penggunaan bahasa baku dalam membuat suatu karya ilmiah.

\section{Ragam Bahasa Indonesia}

Ada berbagai faktor yang mempengaruhi penggunaan bahasa, misalnya siapa pembicaranya, pendengar yang dihadapi, kondisi, situasi, ruang dan waktu. Komunikasi antara raja dan hamba akan berbeda dengan antar rekan sejawat, demikian pula berkomunikasi secara berhadapan akan berbeda dengan berkomunikasi melalui surat. Apa yang disampaikan pada suatu rapat belum tentu dapat dimengerti orang yang tidak hadir pada rapat tersebut. Hal ini melahirkan sejumlah ragam bahasa. Adanya bermacam-macam ragam bahasa, ini sesuai dengan fungsi, kedudukan serta lingkungan yang berbeda-beda.

Bahasa Indonesia yang amat luas wilayah pemakaiannya dan bermacam ragam penuturnya, mau tidak mau, takluk pada hukum perubahan. Arah perubahan itu tidak selalu tak terelakkan karena kita pun dapat mengubah secara berencana. Faktor sejarah dan perkembangan masyarakat turut pula berpengaruh pada timbulnya sejumlah ragam bahasa Indonesia. Ragam bahasa yang beraneka macam itu masih tetap disebut "bahasa Indonesia" karena masing-masing inti sari bersama yang umum. Ciri dan kaidah tata bunyi, pembentukan kata, tata makna, umumnya sama. Itulah sebabnya kita masih dapat memahami orang lain yang berbahasa Indonesia walaupun di samping itu kita dapat mengenali beberapa perbedaan dalam perwujudan bahasa Indonesianya (Moeliono, 1988).

Istilah ragam dapat disejajarkan dengan variasi. Seperti halnya jika orang mengatakan bahwa modelnya sangat beragam, di dalamnya terkandung maksud bahwa modelnya sangat bervariasi. Adanya ragam atau variasi mengimplikasikan bahwa dari berbagai ragam atau variasi itu terdapat satu model yang menjadi acuannya. Dengan demikian, bagaimanapun model variasinya pastilah terdapat intisari atau ciri-ciri umum yang sama. Jika variasi itu sudah menyimpang jauh dari inti yang menjadi acuannya, itu berarti bahwa sudah bukan variasi dari acuannya, melainkan merupakan model baru (Suharsono, 1993).

\section{Ragam Baku Tulis}

Ragam baku disebut juga ragam ilmiah. Ragam ini merupakan ragam bahasa orang berpendidikan yakni bahasa dunia pendidikan. Ragam ini jugalah yang kaidah-kaidahnya paling lengkap diperikan jika dibandingkan dengan ragam bahasa yang lain. Ragam itu tidak saja ditelaah dan 
diperikan, tetapi juga diajarkan di sekolah. Apa yang dahulu disebut bahasa Melayu Tinggi dikenal juga sebagai bahasa sekolah. Sejarah umum perkembangan bahasa menunjukkan bahwa ragam itu memperoleh gengsi dan wibawa yang tinggi karena ragam itu juga yang dipakai oleh kaum yang berpendidikan dan yang kemudian dapat menjadi pemuka di berbagai bidang kehidupan yang penting. Pejabat pemerintah, hakim, pengacara, perwira, sastrawan, pemimpin perusahaan, wartawan, guru, generasi demi generasi terlatih dalam ragam sekolah itu. Ragam itulah yang dijadikan tolok ukur bagi pemakai bahasa yang benar. Fungsinya sebagai tolok menghasilkan nama bahasa baku atau bahasa standar baginya (Moeliono, 1988).

Ada dua macam ragam bahasa baku, yaitu bahasa baku lisan dan bahasa baku tulisan. Adakalanya bahasa baku lisan suatu bahasa tidak sama dengan bahasa baku tulisnya (Badudu, 1992). Misalnya dapat dijumpai dalam struktur kalimat sebagai berikut.

1. Saya akan membeli buku itu.

2. Akan saya beli buku itu.

3. Buku itu akan saya beli.

4. Saya akan beli buku itu.

5. Buku itu saya akan beli.

Dalam ragam tulisan bahasa Indonesia, struktur yang baku hanyalah kalimat 1, 2, dan 3. Kalimat 4 dan 5 tidak tergolong dalam kalimat baku. Akan tetapi, kalimat 4 dan 5 adalah kalimat baku dalam bahasa lisan.

Tradisi baku dalam bahasa Indonesia adalah bahasa tulis. Berbahasa lisan yang baku dalam kegiatan resmi ialah berbahasa seperti bentuk dan susunan bahasa tulis. Aturan bahasa baku tulis itulah yang dituliskan dalam buku-buku tata bahasa. Menyimpang dari aturan itu disebut tidak baku atau nonbaku.

\section{Penulisan Karya Tulis Ilmiah dengan Bahasa Baku}

Ragam bahasa yang digunakan dalam karya tulis ilmiah menunjukkan bahasa yang sesuai dengan bidangnya, yaitu ragam keilmuan. Sudah selayaknya bahasa yang dipakai adalah bahasa Indonesia baku. Ciri bahasa baku sebagaimana dikemukakan Meoliono (1988) adalah a) mempunyai kemantapan dinamis, artinya kaidah bahasa itu bersifat tetap dan tidak berubah setiap saat, b) sifat kecendekiaanya, artinya perwujudan satuan bahasa yang mengungkapkan penalaran yang teratur dan logis, dan c) adanya proses penyeragaman kaídah bukan penyamaan ragam bahasa, atau penyeragaman variasi bahasa.

Sifat kecendekiaan juga merupakan ciri bahasa baku. Ragam baku bersifat cendekia karena ragam baku dipakai pada tempat-tempat resmi. Pewujud ragam baku ini adalah orang-orang yang terpelajar atau cendekia. Di samping itu, ragam baku dapat dengan tepat memberikan gambaran apa yang menjadi maksud dari pembicara atau penulis.

Ragam baku bersifat seragam. Pada hakikatnya, proses pembakuan bahasa ialah proses penyeragaman bahasa. Dengan kata lain, pembakuan bahasa adalah pencarian titik-titik keseragaman.

Setelah dikenali ciri-ciri bahasa baku, berikut ini dijabarkan pembakuan di bidang ejaan, lafal, kata, dan kalimat. Berikut ini akan dipaparkan penggunaannya.

1. Ejaan

Ejaan dapat diartikan sebagai pelambangan bunyi-bunyi bahasa sesuai dengan huruf, baik berupa huruf demi huruf maupun huruf yang sudah disusun menjadi kata, kelompok kata (frasa), atau kalimat. Secara umum, ejaan berarti keseluruhan ketentuan yang mengatur pelambangan bunyi bahasa, termasuk pemisahan dan penggabungannya, yang dilengkapi pula dengan penggunaan tanda baca (Mustakim, 1992).

Selanjutnya dikatakan bahwa dalam suatu bahasa sistem ejaan lazimnya 
mempunyai tiga aspek, yaitu aspek fonologis, yang menyangkut pelambangan fonem dengan huruf dan penyusunan abjad; aspek morfologis, yang menyangkut pelambangan ujaran dengan tanda baca.

Dengan demikian, ketentuan yang mengatur pelambangan fonem dengan huruf, penyesuaian huruf-huruf asing dengan huruf yang ada dalam bahasa Indonesia, serta pelafalan, pengakroniman dan penyusunan abjad termasuk di dalam aspek fonologis. Ketentuan yang mengatur pembentukan kata dengan pengimbuhan, penggabungan kata, pemenggalan kata, penulisan kata, dan penyerapan kosakata asing ke dalam bahasa Indonesia termasuk aspek morfologis. Di pihak lain, penulisan dan pelafalan frasa, klausa, serta kalimat termasuk aspek sintaksis. Satuan-satuan sintaksis itu dalam pelafalannya mengandung unsur suprasegmental, seperti intonasi, tekanan, dan jeda, yang dalam ragam bahasa tulis perlu dilambangkan dengan tanda baca, misalnya tanda titik, titik koma, tanda seru, tanda tanya, dan tanda baca yang lain.

\section{Aspek Fonologis}

Kaidah dalam aspek fonologis ragam baku bahasa Indonesia antara lain menyangkut penulisan huruf, pelafalan, dan pengakroniman. Penulisan huruf bahasa Indonesia menyangkut soal abjad, vokal, diftong, konsonan, persukuan, dan nama diri.

Dalam aspek fonologis, termasuk di dalamnya adalah kaidah penulisan huruf, yaitu huruf besar atau huruf kapital dan huruf miring. Menurut Pedoman Umum Ejaan Bahasa Indonesia Yang Disempurnakan (2000) huruf besar atau huruf kapital digunakan untuk penulisan berikut:

a. Huruf kapital atau huruf besar dipakai sebagai unsur pertama kata pada awal kalimat.

b. Huruf kapital dipakai sebagai huruf pertama petikan langsung. c. Huruf kapital dipakai sebagai huruf pertama dalam ungkapan yang berhubungan dengan nama Tuhan dan Kitab Suci, termasuk kata ganti untuk Tuhan.

d. Huruf kapital dipakai sebagai huruf pertama nama gelar kehormatan, keturunan, dan keagamaan yang diikuti nama orang.

e. Huruf kapital dipakai sebagai huruf pertama unsur nama jabatan dan pangkat yang diikuti nama orang atau yang dipakai sebagai pengganti nama orang tertentu, nama instansi, atau nama tempat.

f. Huruf kapital dipakai sebagai huruf pertama unsur-unsur nama orang.

g. Huruf kapital dipakai sebagai huruf pertama nama bangsa, suku bangsa, dan bahasa.

h. Huruf kapital dipakai sebagai huruf pertama nama tahun, bulan, hari, hari raya,, dan peristiwa sejarah.

i. Huruf kapital dipakai sebagai huruf pertama nama geografi.

j. Huruf kapital dipakai sebagai huruf pertama semua unsur nama negara, lembaga pemerintah dan ketatanegaraan, serta nama dokumen resmi, kecuali kata seperti dan.

k. Huruf kapital dipakai sebagai huruf pertama setiap unsur bentuk ulang sempurna yang terdapat pada nama badan, lembaga pemerintah dan ketatanegaraan, serta dokumen resmi.

1. Huruf kapital dipakai sebagai huruf pertama semua kata (termasuk semua unsur kata ulang sempurna) di dalam nama buku, majalah, surat kabar dan judul karangan, kecuali kata seperti di, ke, dari, dan, yang, untuk yang tidak terletak pada posisi awal.

m. Huruf kapital dipakai sebagai huruf pertama unsur singkatan nama gelar, pangkat, dan sapaan.

n. Huruf kapital dipakai sebagai huruf pertama penunjuk hubungan kekerabatan seperti bapak, ibu, saudara, kakak, adik, dan paman yang dipakai dalam penyapaan dan pengacuan. 
o. Huruf kapital dipakai sebagai huruf pertama kata ganti Anda.

Adapun penulisan huruf miring menurut Pedoman Umum Ejaan Bahasa Indonesia Yang Disempurnakan (2000) adalah sebagai berikut:

a. Huruf miring dalam cetakan dipakai untuk menuliskan nama buku, majalah dan surat kabar yang dikutip dalam tulisan.

b. Huruf miring dalam cetakan dipakai untuk menegaskan atau mengkhususkan huruf, bagian kata, kata, atau kelompok kata.

c. Huruf miring dalam cetakan dipakai untuk menuliskan nama ilmiah atau ungkapan asing, kecuali yang telah disesuaikan ejaannya.

Selain penulisan huruf, pelafalan juga penting dalam kesempurnaan aspek fonologis. Beberapa contoh, misalnya, bagaimanakah melafalkan huruf a pada kata Allah dan kata serapan lain dari bahasa Arab? Manakah pelafalan yang benar (ta'at) atau (taat) atau (ubah) atau (rubah)? Bagaimanakah melafalkan $h$ dan e yang tepat?

Kaidah penyingkatan dan pengakroniman pun ada dalam bahasa Indonesia ragam baku. Singkatan berbeda dengan akronim.Singkatan adalah kependekan yang berupa huruf atau gabungan huruf, baik dilafalkan huruf demi huruf maupun dilafalkan dengan mengikuti bentuk lengkapnya. Beberapa singkatan yang dilafalkan huruf demi huruf dapat diperhatikan dalam contoh berikut ini: SMP, DPR, BRI, dan lain-lain. Singkatan ini dapat juga dilafalkan sesuai dengan bentuk lengkapnya. Singkatan yang dilafalkan dengan bentuk lengkapnya adalah Bpk., Sdr., dst., ybs., dhi., tsb., d.a., a.n., dsb., dll., dan sebagainya. Singkatan lambang adalah singkatan yang terdiri atas satu huruf atau lebih yang melambangkan konsep dasar ilmiah, seperti kuantitas, satuan, dan unsur. Dalam penulisannya, singkatan lambang berbeda dengan singkatan-singkatan lain, baik singkatan umum maupun singkatan nama diri. Perbedaan itu tidak hanya terletak pada cara penulisannya, tetapi juga penandaannya. Dengan demikian, berbagai kesatuan yang berkenaan dengan penulisan dan penandaan pada singkatan umum dan singkatan nama diri tidak berlaku bagi singkatan lambang. Hal ini terjadi karena penulisan dan penandaan singkatan lambang pada umumnya disesuaikan dengan peraturan internasional. Dalam hal ini, singkatan lambang penulisannya tidak diikuti dengan tanda titik.

Akronim adalah kependekan yang berupa gabungan huruf awal, gabungan suku kata, atau gabungan huruf awal dan suku kata, yang ditulis dan dilafalkan seperti halnya kata biasa. Misalnya: simpedes, pilkada, ketoprak, dan pramuka. Akronim dilafalkan seperti halnya kata biasa, sedangkan singkatan dilafalkan huruf demi huruf, ada pula yang dilafalkan sesuai dengan bentuk lengkapnya, misalnya: $\mathrm{m}, \mathrm{g}$, dan 1 .

\section{Aspek Morfologis}

Kaidah ragam baku bahasa Indonesia yang menyangkut aspek morfologis adalah kata, baik pengimbuhan, penggabungan, pemenggalan, penulisan, maupun penyesuaian kosakata asing. Kata dasar, kata turunan (kata jadian), kata ulang, gabungan kata-kata ganti, kata depan, kata si dan sang, partikel, penulisan unsur serapan, tanda baca, dan penulisan angka dan bilangan penting untuk diperhatikan dalam ragam baku bahasa Indonesia.

Kata yang berupa kata dasar ditulis sebagai satu satuan. Dalam hal kata turunan, ada beberapa hal yang perlu diperhatikan mengenai penulisan kata turunan: 1) imbuhan ditulis serangkai dengan kata dasarnya; 2) awalan atau akhiran ditulis serangkai dengan kata yang langsung mengikuti atau mendahuluinya kalau bentuk dasarnya berupa gabungan kata; 3) kalau bentuk dasar berupa gabungan kata sekaligus mendapat awalan dan akhiran, kata-kata itu ditulis serangkai; 
4) kalau salah satu unsur gabungan kata hanya dipakai dalam kombinasi, gabungan kata itu ditulis serangkai.

Dalam hal penulisan bentuk terikat, bila bentuk terikat tersebut diikuti oleh kata yang huruf awalnya huruf kapital, di antara kedua unsur itu dituliskan tanda hubung (). Maha sebagai unsur gabungan kata ditulis serangkai kecuali diikuti oleh kata yang bukan kata dasar dan kata esa. Bentuk ulang ditulis secara lengkap dengan menggunakan tanda hubung.

Dalam hal gabungan kata, ada beberapa hal yang perlu diperhatikan mengenai penulisannya. (1) Gabungan kata yang lazim disebut kata majemuk, termasuk istilah khusus, bagian-bagiannya umumnya ditulis terpisah. (2) Gabungan kata, termasuk istilah khusus, yang mungkin menimbulkan salah baca, dapat diberi tanda hubung yang menegaskan pertalian di antara unsur yang bersangkutan. (3) Gabungan kata yang sudah dianggap sebagai satu kesatuan ditulis serangkai.

Kata ganti $k u$ dan kau ditulis serangkai dengan kata yang mengikutinya; $k u, m u$, dan nya ditulis serangkai dengan kata yang mendahuluinya. Kata depan $d i$, $k e$, dan dari ditulis terpisah dari kata yang mengikutinya, kecuali di dalam gabungan kata yang sudah dianggap sebagai satu kata seperti kepada dan daripada. Kata si dan sang ditulis terpisah dari kata yang mengikutinya

Ada beberapa partikel yang berhubungan dengan masalah penulisan kata. Partikel lah, kah, tah ditulis serangkai dengan kata yang mendahuluinya. Partikel pun ditulis terpisah dari kata yang mendahuluinya, kecuali pun dalam kelompok kata yang sudah dianggap padu benar ditulis serangkai, misalnya adapun, andaipun, ataupun, bagaimanapun, betapapun, biarpun, kalaupun, kendatipun, maupun, sekalipun, sungguhpun, dan walaupun.
Ada beberapa hal yang perlu diperhatikan mengenai penulisan angka dan bilangan. (1) angka dipakai untuk menyatakan lambang bilangan atau nomor. Di awal tulisan lazim digunakan angka Arab dan angka Romawi. (2) Angka digunakan untuk menyatakan: ukuran panjang, berat, isi, satuan waktu, dan nilai uang. (3) Angka lazim dipakai untuk memberi nomor jalan, rumah, apartemen, atau kamar pada alamat. (4) Angka digunakan juga untuk memberi nomor karangan atau bagiannya. (5) Penulisan lambang bilangan dengan huruf dilakukan dengan mempertimbangkan sebagai bilangan utuh dan bilangan pecahan. (6) Penulisan kata bilangan tingkat dapat dilakukan dengan berbagai cara. (7) Penulisan kata bilangan yang mendapat akhiran -an dilakukan dengan menuliskan akhiran -an itu di belakang angka. (8) Lambang bilangan yang dapat dinyatakan dengan satu atau dua kata ditulis dengan huruf kecuali jika beberapa lambang bilangan itu dipakai secara berurutan; seperti dalam perincian dan pemaparan. (9) Lambang bilangan pada awal kalimat ditulis dengan huruf; jika perlu, susunan kalimat diubah sehingga bilangan yang tidak dapat dinyatakan dengan satu atau dua kata tidak terdapat lagi pada awal kalimat. (10) Angka yang menunjukkan bilangan bulat yang besar dapat dieja sebagian supaya mudah dibaca. (11) Kecuali di dalam dokumen resmi seperti akta dan kuitansi, bilangan tidak perlu ditulis dengan angka dan huruf sekaligus dalam teks. (12) Kalau bilangan dilambangkan dengan angka dan huruf, penulisannya harus tepat.

Perkembangan bahasa Indonesia sangat pesat. Dalam perkembangannya itu bahasa Indonesia menyerap unsur dari pelbagai bahasa lisan, baik dari bahasa daerah maupun bahasa asing seperti bahasa Sansekerta, Arab, Portugis, Belanda, dan Inggris. Berdasarkan taraf integrasinya, unsur pinjaman dan bahasa Indonesia dapat dibagi atas dua golongan besar. Pertama, unsur asing yang belum sepenuhnya terserap ke dalam bahasa Indonesia, seperti 
shuttle cook. Unsur-unsur ini dipakai dalam konteks bahasa Indonesia, tetapi pengucapannya masih mengikuti cara asing. Kedua, unsur asing yang pengucapan dan penulisannya disesuaikan dengan kaidah bahasa Indonesia.Dalam hal ini usahakan agar ejaan asing hanya diubah seperlunya sehingga bentuk Indonesianya masih dapat dibandingkan dengan bentuk asalnya. Unsur serapan dalam bahasa Indonesia pada garis besarnya menyangkut tiga hal, yaitu: (a) gabungan vokal, vokal tunggal; (b) gabungan konsonan, konsonan tunggal; dan (c) gabungan vokal-konsonan atau konsonan-vokal yang berupa akhiran.

Untuk lebih jelasnya, perihal ejaan dan istilah dapat dibaca Pedoman Umum Ejaan Bahasa Indonesia Yang Disempurnakan dan Pedoman Umum Pembentukan Istilah.

Dalam uraian di atas telah dibicarakan pemakaian huruf, penulisan huruf, penulisan kata, penulisan unsur serapan dan pembentukan istilah. Tidak kalah pentingnya dengan hal itu ialah kaidah mengenai tanda baca. Tanda baca yang perlu diperhatikan dalam ragam baku bahasa Indonesia ialah tanda titik (.), tanda koma (,), tanda titik koma (;), tanda titik dua $(:)$, tanda hubung (-), tanda pisah (-), tanda elips (...), tanda tanya (?), tanda kurung $((\ldots))$, tanda kurung siku ([...]), tanda petik (“...”), tanda petik tunggal ('...'), tanda garis miring (/), dan tanda menyingkatkan atau apostrof ('). Hal-hal yang berkaitan dengan kaidah penulisan tanda baca dapat dilihat pada Pedoman Umum Ejaan Bahasa Indonesia Yang Disempurnakan.

\section{Aspek Sintaksis}

Kaidah ragam baku bahasa Indonesia yang menyangkut aspek sintaksis meliputi frasa, klausa, dan kalimat. Berikut ini diuraikan serangkaian contoh yang menyangkut ketiga hal itu.

Perihal frasa misalnya, mana yang benar, orang tua-tua, orang tua-orang tua? Orang tua yang berupa kata majemuk berarti 'ibu-bapak'; dapat pula frasa itu berarti 'orang yang tua'. Karena kedua kata itu berbeda bentuk dan maknanya, bentuk ulangnya pun harus dibedakan (Badudu, 1989). Perhatikan kedua kalimat berikut.

a. Sekolah itu mengadakan pertemuan antara guru-guru dengan orang-orang tua murid.

b. Yang boleh menjadi anggota perkumpulan itu hanyalah orang tuatua.

Dengan bentuk pengulangan kata itu dalam kedua kalimat di atas, jelas bahwa orang-orang tua murid ialah "para ibubapak murid', sedangkan orang tua-tua ialah 'orang-orang yang sudah tua' (dalam pengertian jamak). Pengulangan kata tua menjadi tua-tua memang menekankan pada sifat tua sebagai lawan sifat muda. Kalau dinyatakan orang tua-tua dan orang mudamuda tentulah yang dimaksud bukan seorang, tetapi banyak. Ada pula yang mengusulkan agar kata majemuk orang tua yang berarti 'ibu bapak' sebaiknya diulang seluruhnya menjadi orang tua-orang tua. Akan tetapi, yang seperti ini menyalahi kaidah bahasa asal bahasa Indonesia, yaitu bahasa Melayu. Dalam bahasa Melayu, baik kata majemuk maupun kelompok kata (frasa) yang diulang hanyalah konstituen pokoknya, sedangkan pewatasnya tidak usah diulang.

Gabungan kata atau kata majemuk jika akan diulang, tidak perlu seluruh unsurnya ditulis ulang. Hal ini karena -jika seluruh unsurnya ditulis ulang- kita akan menghadapi masalah yang cukup rumit, terutama apabila kita ingin mengulang gabungan kata yang bentuknya cukup panjang, seperti kereta api cepat luar biasa.

Atas dasar pertimbangan itu, kebijaksanaan yang ditempuh adalah bahwa pengulangan gabungan kata tidak perlu ditulis ulang seluruhnya, tetapi cukup dengan mengulang unsur yang pertama saja (Mustakim, 1992).

Meskipun demikian, harus diakui bahwa ada yang berubah dalam bahasa Indonesia sehingga tidak lagi sama dengan 
bahasa Melayu dulu. Dalam buku Tata Bahasa Baku Bahasa Indonesia (1988) ada kata yang terbentuk dari dua morfem yang dituliskan serangkai seperti sepatah kata saja, misalnya hulubalang. Kalau kata gabung itu dituliskan serangkai seperti tidak lagi dipersoalkan bagaimana bentuk ulangnya; sekiranya kata-kata itu akan diulang, tentulah diulang seluruhnya.

Angka dua sebagai penanda perulangan tidak digunakan di dalam EYD. Dalam hal ini kata atau bagian-bagian kata yang diulang ditulis kembali secara lengkap dengan menyertakan tanda hubung di antara unsur yang diulang. Dengan demikian, dalam tulisan-tulisan yang bersifat resmi, misalnya naskah buku, karya tulis, laporan ilmiah, skripsi, dan berbagai karya tulis resmi yang lain bentuk ulang harus ditulis secara lengkap, tidak menggunakan angka dua.

Dalam hal cara menuliskan bentuk ulang yang mengalami perubahan fonem, seperti halnya kata ulang yang lain, pada kata itu pun unsur yang diulang ditulis kembali secara lengkap dengan disertai tanda hubung di antara keduanya. Jadi, unsur yang diulang itu tidak ditulis dengan angka 2 ataupun ditulis ulang tanpa tanda hubung, misalnya gerak-gerik.

Dalam bahasa Indonesia dewasa ini, ada kecenderungan orang untuk selalu mengulang kata benda bila ingin menyatakan jamak, padahal dalam bahasa Indonesia ada cara lain untuk menyatakan jamak itu yaitu dengan menggunakan kata semua, banyak, beberapa, segala. Sering juga orang mengulang kata benda untuk menyatakan pengertian jamak, padahal pengulangan itu sebenarnya tidak perlu karena kata itu mengandung arti umum sehingga mencakup semua. Contoh: orang yang melanggar undang-undang akan dihukum. Kata orang dalam kalimat itu tidak perlu dijadikan orang-orang karena yang dimaksud adalah 'semua orang' atau 'siapa saja'.
Dalam bahasa Indonesia juga tidak dikenal apa yang disebut concord atau agreement. Kita mengatakan beberapa orang dan bukan beberapa orang-orang karena makna jamaknya itu sudah cukup dinyatakan oleh kata-kata beberapa itu. Kata bendanya tidak perlu dijamakkan. Begitu juga para menteri sudah menunjukkan jamak tidak perlu dijadikan para menteri-menteri.

Perihal kata menyangkut pula idiom. Yang dimaksudkan dengan idiom ialah gabungan yang sudah teradat dan yang maknanya tidak dengan serta-merta dapat dijabarkan dari makna unsurnya masingmasing misalnya meninggal dunia, air muka, mata pisau, besar hati, luar kepala, bermulut besar. Mengenali idiom suatu bahasa biasanya dicapai setelah belajar bahasa itu lama-lama. Kita dapat membedakan seorang penutur asli dengan yang bukan justru dengan memperhatikan ada tidaknya penggunaan idiom dalam ujarannya. Orang akan dianggap fasih berbahasa atau penerjemah yang terampil, jika menguasai tata bahasa dan idiom bahasa tersebut dengan baik (Moeliono, 1984).

Dalam aspek sintaksis, seringkali ditemui kesalahan berbahasa ragam baku dalam hal penulisan subjek berkata depan, objek berkata depan, kalimat pasif bentuk diri, penghubung kalimat majemuk, pemakaian bentuk di mana, dalam mana, di dalam mana, dari mana, dan yang mana sebagai penghubung, pemakaian kata depan yang tidak tepat, penghilangan kata depan, penghilangan afiks, akhiran - $i$ dan -kan, afiks pen-/-an, pemakaian bentuk yang mubazir dan pemilihan kata (Ramlan, 1992).

Contoh kesalahan kalimat dengan subjek berkata depan adalah berikut ini. $D i$ dalam keputusan itu menunjukkan kebijaksanaan yang dapat menguntungkan masyarakat umum. Secara sepintas kalimat itu termasuk kalimat yang benar, tetapi jika diamati dengan saksama ternyata kalimat 
itu mengandung kesalahan. Kesalahan tersebut berkaitan dengan fungsi subjek. Berdasarkan analisis fungsional, $S$ yang dimaksudkan oleh penulis dalam kalimat itu ialah di dalam keputusan itu. Tentu saja,frasa ini bukan merupakan frasa benda, melainkan frasa depan atau frasa preposisional dengan kata depan di dalam. Dengan demikian, kalimat belum memenuhi kaidah bahasa Indonesia karena fungsi S nya tidak diisi oleh kata atau frasa benda. Pembetulan terhadap kalimat itu dilakukan dengan menghilangkan kata depan di dalam yang terdapat di tempat $\mathrm{S}$ sehingga kalimatnya menjadi keputusan itu menunjukkan kebijaksanaan yang dapat menguntungkan masyarakat umum.

Penghilangan kata depan yang terdapat pada fungsi $\mathrm{S}$ bukanlah satusatunya cara untuk membetulkan kalimat itu. Itu, misalnya, dapat dibetulkan dengan cara mengubah $\mathrm{P}$ kata kerja menunjukkan yang berawalan meN- menjadi $\mathrm{P}$ kata kerja yang berawalan di- sehingga kalimatnya menjadi Di dalam keputusan itu ditunjukkan kebijaksanaan yang dapat menguntungkan masyarakat umum.

Kesalahan yang lebih umum ditemui ialah kesalahan yang berupa objek (O) berkata depan atau objek yang diisi oleh frasa depan, misalnya banyak anggota masyarakat belum menyadari akan pentingnya kesehatan lingkungan.

Kalimat di atas memiliki $\mathrm{O}$ yang berfrasa depan, yaitu frasa yang didahului oleh kata depan. Objek yang dimaksud adalah akan pentingnya kesehatan lingkungan. Objek yang diisi oleh frasa depan itu harus dihindari sebab menurut kaidah kalimat bahasa Indonesia yang umum $\mathrm{O}$ kalimat tidak boleh berupa frasa depan. Oleh karena itu, kalimat itu diperbaiki dengan cara menghilangkan kata depannya menjadi sebagai berikut. Banyak anggota masyarakat belum menyadari pentingnya kesehatan lingkungan.

Kesalahan seperti ini disebabkan oleh kerancuan pemakaian kata kerja yang memang berkata depan dengan kata kerja transitif yang tidak berkata depan. Memang, terdapat kata kerja berkata depan yang hampir sama artinya dengan kata kerja transitif. Contohnya adalah berbicara tentang $=$ membicarakan, suka akan =menyukai,tahu akan/tentang= mengetahui. Akan tetapi, jika bentuk transitif yang digunakan, kata depannya harus dihilangkan.

Kalimat pasif bentuk diri merupakan salah satu contoh kesalahan aspek sintaksis dalam ragam baku bahasa Indonesia.

Rambu-rambu yang terdapat di jalan raya kamu harus perhatikan. Sepintas lalu kalimat itu merupakan kalimat yang benar, tetapi jika diperiksa dengan teliti, ternyata kalimat itu salah. Kesalahan itu terletak pada penggunaan kami harus perhatikan. Kesalahan ini dapat dibetulkan dengan mengubah susunannya menjadi harus kamu perhatikan sehingga kalimatnya menjadi Rambu-rambu yang terdapat di jalan raya harus kamu perhatikan.

Selain itu, kalimat majemuk memiliki bentuk yang lebih kompleks dari pada kalimat tunggal karena jumlah klausa yang membentuknya lebih banyak. Kalimat tunggal hanya terdiri dari sebuah klausa, sedangkan kalimat majemuk terdiri atas dua klausa atau lebih.

Kalimat majemuk sebenarnya terbentuk dari penggabungan kalimatkalimat tunggal. Dalam penggabungan itu sering terjadi penggantian dan penghilangan serta pengulangan unsurunsur yang sama. Berdasarkan kedudukan klausa-klausa pembentuknya, kalimat majemuk dapat dibedakan menjadi dua macam, yaitu kalimat majemuk setara dan kalimat majemuk bertingkat.

Sehubungan dengan penyusunan kalimat majemuk tersebut, terdapat dua jenis kesalahan yang sering ditemui, yaitu penggunaan kata penghubung yang kurang tepat dan penggunaan kata penghubung setara pada awal kalimat. Kesalahan 
kalimat berikut ini disebabkan oleh kekurangtepatan pemilihan kata penghubung. Penanaman rumput gajah bagi masyarakat pedesaan berguna untuk menyediakan makanan ternak juga mencegah adanya penggembalaan liar. Pemakaian kata juga dalam kalimat itu tidak tepat. Seharusnya diganti dengan kata dan sebab kata juga tidak lazim digunakan untuk menghubungkan klausa-klausa yang kedudukannya setara.

Di dalam bahasa Indonesia sering dijumpai pemakaian bentuk-bentuk $d i$ mana, dalam mana, di dalam mana, dari mana, dan yang mana sebagai penghubung. Penggunaan bentuk-bentuk tersebut kemungkinan besar dipengaruhi oleh bahasa asing, khususnya bahasa Inggris where, in which, dan which. Dalam bahasa Indonesia karena sudah ada penghubung yang lebih tepat, yaitu kata tempat dan yang sehingga kalimat-kalimat yang menggunakan kata-kata itu harus dirubah, misalnya: Rumah tempat ia tinggal sangat luas. Sektor pariwisata yang merupakan tulang punggung perekonomian negara harus senantiasa ditingkatkan. Dalam bahasa Indonesia memang terdapat bentukbentuk itu, tetapi tidak lazim digunakan sebagai penghubung. Bentuk-bentuk itu lazimnya dipakai untuk menandai kalimat tanya.

Dalam bahasa Indonesia terdapat kata-kata seperti di, ke, dari, pada, terhadap, tentang, oleh, dan sebagainya. Kata-kata semacam itu tidak dapat berdiri sendiri sebagai subjek dan predikat serta fungsi-fungsi klausa yang lain. Kata-kata tersebut dapat dikatakan tidak pernah mengalami perubahan bentuk. Selain itu, kata-kata itu berfungsi sebagai penanda dalam frasa eksosentris seperti tampak dalam di rumah, ke Jakarta, dari Amir, pada orang, terhadap tanah air, tentang ilmu, oleh Tuti, dan sebagainya. Kata-kata yang mempunyai ciri semacam itu biasa disebut kata depan atau preposisi. Dalam penggunaan bahasa, orang harus cermat dengan kata depan karena kata depan itu secara semantik menandai pertalian antara kata atau frasa yang mengikutinya, atau yang disebut aksis, dengan kata atau frasa lain dalam kalimat atau frasa yang lebih besar.

Dari pengamatan terhadap pemakaian bahasa Indonesia dapat diketahui bahwa kata depan daripada-lah yang sering digunakan secara tidak tepat. Ketidaktepatan pemakaian kata depan ini disebabkan oleh tidak dikuasainya kaidah pemakaian kata itu oleh penutur bahasa. Kata depan daripada dipakai untuk menandai makna perbandingan yang menyatakan bahwa terbanding itu lebih dibandingkan dengan pembandingnya. Jika tidak ada perbandingan, kata depan daripada tidak digunakan.

Dalam bahasa Indonesia terdapat bermacam-macam kata depan. Menurut hasil penelitian tercatat 115 kata depan. Kata depan ialah kata yang menandai pertalian makna kata atau frasa yang mengikutinya dengan kata atau frasa lain dalam suatu kalimat. Pemakaian kata depan dalam kalimat sangat penting karena pemakaian itu untuk menandai makna atau frasa yang mengikutinya. Misalnya: Sesuai dengan tujuan pembicaraan makalah ini berbicara mengenai ragam baku bahasa Indonesia. Sikap mengabaikan penulisan kata depan dalam ragam baku bahasa Indonesia tidak dibenarkan.

Ragam baku bahasa Indonesia digunakan dalam situasi resmi. Dalam situasi resmi orang cenderung menggunakan bahasa secara lengkap, sedangkan dalam situasi tidak resmi atau santai orang cenderung menggunakan bahasa secara tidak lengkap. Ketidaklengkapan itu misalnya karena adanya penghilangan unsur-unsur tertentu. Salah satu unsur yang sering dihilangkan adalah afiks. Afiks yang sering dihilangkan adalah ber- dan meN- seperti terlihat pada contoh berikut ini. (1) Dalam makalah ini saya akan bicara tentang ragam baku bahasa Indonesia. (2) Pagi ini pemerintah 
berangkatkan $50 \quad$ KK $\quad$ ke lokasi transmigrasi.

Pada contoh (1) terdapat penghilangan ber- pada kata bicara, sedangkan pada contoh (2) terdapat penghilangan afiks meN- pada kata berangkatkan. Kedua contoh itu hanya boleh digunakan pada situasi tidak resmi sebab dalam situasi ini kelengkapan tuturan tidak dipentingkan dan yang diutamakan ialah pemahaman.

Dalam kenyataan berbahasa Indonesia pemakaian akhiran $-i$ dan $-k a n$ sering dikacaukan. (1) Kepergianku tidak membawakan hasil yang memuaskan. (2) Orang itu dihadiahkan uang satu juta rupiah oleh pemerintah. Pengacauan seperti ini terjadi karena kurang atau tidak disadari bahwa akhiran $-i$ dan -kan tidak sama. Ketidaksamaan antara keduanya terletak pada makna yang dinyatakannya. Pada contoh (1) akhiran -kan sebaiknya tidak digunakan karena tidak menyatakan makna apa-apa. Yang menyatakan makna pada contoh (1) itu hanyalah awalan meN-. Kekacauan yang terjadi pada contoh (2) terletak pada kesalahan pemakaian akhiran -kan. Akhiran -kan tidak dapat menyatakan makna memberi apa yang tersebut pada kata yang dilekati. Yang dapat menyatakan makna itu ialah akhiran - $i$. Oleh karena itu, pemakaian akhiran -kan pada kalimat (2) tersebut tidak tepat dan harus diganti dengan akhiran $-i$.

Selain hal-hal yang telah diuraikan di atas, kemubaziran sering dijumpai, yang seharusnya tidak terjadi dalam ragam baku bahasa Indonesia. Istilah mubazir maksudnya terlampau banyak, berlebihlebihan sehingga sia-sia saja atau tidak berguna, misalnya sebab karena, oleh sebab karena, agar supaya, adalah merupakan, lalu kemudian, beberapa kaset-kaset, dan lain-lain.

\section{Penutup}

Bahasa dalam penulisan karya tulis ilmiah harus menggunakan ragam bahasa baku. Kebakuan itu menyangkut kaidah ejaan, kata, dan kalimat. Bahasa karya tulis ilmiah merupakan bahasa formal. Ada aturan-aturan formal yang harus ditaati.

Dengan menaati kaidah bahasa baku, diharapkan karya tulis ilmiah itu dapat dipahami secara baik oleh pembacanya. Pemilihan ragam baku untuk penulisan karya tulis itu dilakukan sesuai dengan penggunaan bahasa sebagai sarana alat komunikasi penulis kepada pembaca.

\section{Daftar Pustaka}

Anton M. Moeliono. (1984). Santun Bahasa. Jakarta: Gramedia.

. (1988). Tata Bahasa Baku Bahasa Indonesia. Jakarta: Balai Pustaka.

E. Zaenal Arifin, S. Amran Tasai. (2010). Cermat Berbahasa Indonesia untuk Perguruan Tinggi. Jakarta: Akademika Pressindo.

J.S., Badudu. (1992). Cakrawala Bahasa Indonesia II. Jakarta: Gramedia.

M. Ramlan dkk. (1992). Bahasa Indonesia yang Salah dan yang Benar. Yogyakarta: Andi Offset.

Mustakim. (1992). Tanya Jawab Ejaan Bahasa Indonesia untuk Umum. Jakarta: Gramedia Pustaka Utama.

Pedoman Umum Ejaan Yang Disempurnakan. (2000). Jakarta: Pusat Bahasa Departemen Pendidikan Nasional. Dapat diakses pada alamat: http://badanbahasa.kemdikbud.go.id/ lamanbahasa/sites/default/files/pedo man umumejaan_yang_disempurnakan.pdf

Pedoman Umum Pembentukan Istilah. (1999). Jakarta: Grasindo.

Suharsono. (1993). Bahasa Indonesia. tidak diterbitkan. 
Jurnal Tarbiyah (Jurnal Ilmiah Kependidikan)

Vol. 6 No. 2. Juli - Desember 2017 (41-51) 